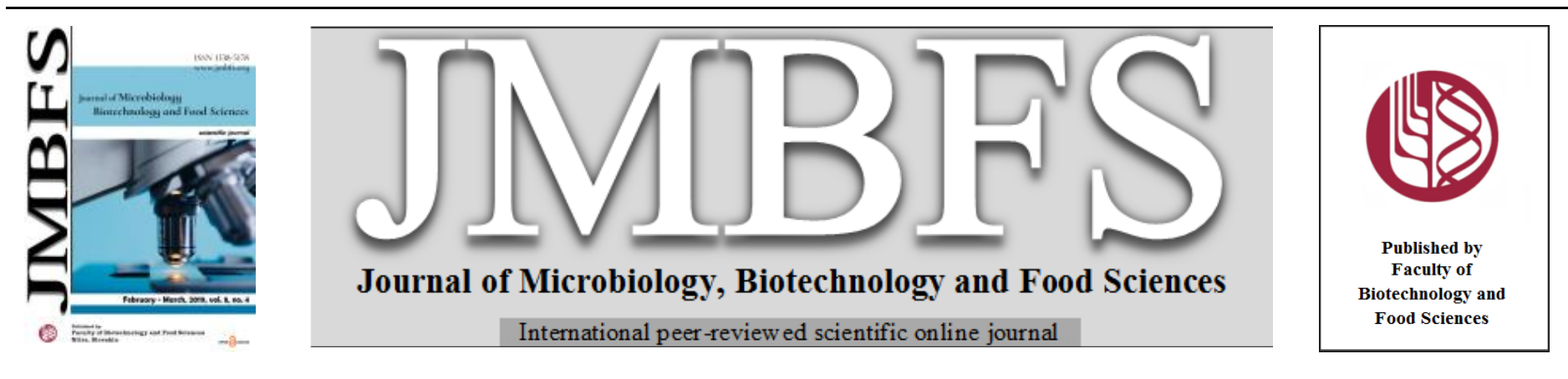

\title{
IDENTIFICATION OF COW MILK ALLERGEN IN THE PRODUCTS OF GRAPE PROCESSING
}

\author{
Lucia Zeleñákovál ${ }^{*}$, Martina Fikselovál, Jana Žiarovská ${ }^{2}$ Anna Kolesárová ${ }^{3}$, Lukáš Jurčaga $^{1}$
}

Address(es): doc. Ing. Lucia Zeleňáková, PhD.

${ }^{1}$ Department of Food Hygiene and Safety, Faculty of Biotechnology and Food Sciences, Slovak University of Agriculture, Tr. A. Hlinku 2, 94976 Nitra, Slovak Republic.

${ }^{2}$ Department of Genetics and Plant breeding, Faculty of Agrobiology and Food Resources, Slovak University of Agriculture, Tr. A. Hlinku 2, 94976 Nitra, Slovak Republic.

${ }^{3}$ Department of Plant Products storage and Processing, Faculty of Biotechnology and Food Sciences, Slovak University of Agriculture, Tr. A. Hlinku 2, 94976 Nitra, Slovak Republic.

*Corresponding author: lucia.zelenakova@uniag.ska

doi: 10.15414/jmbfs.2019.8.4.1098-1102

ARTICLE INFO

Received 28. 6. 2018

Revised 18. 10. 2018

Accepted 13. 11. 2018

Published 1. 2. 2019

Regular article

open $\partial_{\text {Access }}$

\begin{abstract}
The aim of research was the identification of cow milk allergen in grapes, must, federweisser and wine by immunochemical method ELISA. Milk allergens (casein) are mostly used together with egg proteins during wine clarification. The results show that quality of calibration curves has significant importance for objective evaluation of quality detection. The degree of the variability calibration samples expressed $\mathrm{R}^{2}$ was not less than 0.9 in both calibration curves (0.9485 and 0.9659$)$. In grape samples, concentrations of cow's milk casein below the detection limit were determined, that is recommended by the ELISA kit manufacturer. All grape samples showed casein concentration less than the value corresponding to $0 \mathrm{ppm}$ standard (from 0.039 to $0.127 \mathrm{mg} / \mathrm{kg}$ ). Low concentrations were recorded in three samples of must (from 0.056 to $0.077 \mathrm{mg} / \mathrm{kg}$ ) as well. In case of the federweisser, the casein concentration ranged from 0.367 to $1.301 \mathrm{mg} / \mathrm{kg}$, which is still less than $1.5 \mathrm{ppm}$ standard $(1.373 \mathrm{mg} / \mathrm{kg})$. Most of the wines were found to be in the ELISA detection range. The exceptions were samples no. 3 and 9, whose absorbance was above the highest standard $(45 \mathrm{mg} / \mathrm{kg})$. These samples were then reconsidered after the first dilution, the resulting cow milk casein concentration was $67.22 \mathrm{mg} / \mathrm{kg}$ and $48.66 \mathrm{mg} / \mathrm{L}$. Higher concentrations of this protein contained white wines (from 21.473 to $67.22 \mathrm{mg} / \mathrm{L}$ ). In red wines, the milk protein concentrations ranged from 1.634 to $16.715 \mathrm{mg} / \mathrm{L}$.
\end{abstract}

Keywords: allergen, casein, allergen in wine, production of wine, ELISA

\section{INTRODUCTION}

Grape is the main fruit crop in several countries. Although many grape-based food products can be found in the market, studies have shown that around $75 \%$ of the world grape production is destined for the wine industry. Grape pomace is an abundant by-product from the wine industry, which consists of the remaining skin, seeds and stalks and represents around $25 \%$ of total grape weight used in the winemaking process (Beres et al., 2017). Wine consumption, if it is drunk sensibly and in moderation, is not harmful to the human body and forms an appropriate part of the diet and is beneficial for health. It is proved by the content of the total polyphenols, especially specific substances such as trans-resveratrol, quercetin and anthocyanins in red wines. In addition, Slovak wines have significant anti-radical capabilities, which allow them to compete with highquality foreign wines (Gažarová et al., 2008, 2010, 2016).

Wine is a beverage resulting from the fermentation of grape must with appropriate processing and additives. The diversity and quality of wine result from the grape variety, soil composition, location, climate and the enological processes used (Peñas et al., 2015).

The use of several products is permitted during winemaking. Some of them are additives and are still present in bottled wine; others are normally removed after treatment and do not leave any residue in the final beverage (Castillo-Sánchez et al., 2006; Castillo-Vergara et al., 2015). Some additives and processing aids used in vinification are proteins, and some of them are provided by foods included amongst the most important allergens (such as milk proteins, egg white proteins, etc.) (Peñas et al., 2015). In principle, proteins can affect wine stability and clarity, a variety of procedures have been developed for their removal from wines (Ferreira et al., 2002). Proteins are present in wines at low levels, most of them having a remarkable technological and economical relevance. Milk and egg proteins are also typically utilized by the winery industry as fining agents to promote wine clarity and to improve wine color, flavor and physical stability (Yokosuka and Singleton, 1995). The formation of protein-polyphenols complexes and tannin-protein aggregates has been often described (Siebert,
1999). These complexes can be further removed by decantation or filtration steps (Castillo-Sánchez et al., 2006).

Among milk proteins, caseins are universally known as suitable agents for binding phenolic compounds and reducing off-flavour ingredients that may affect wine taste and colour. Although it is assumed that fining agents are nearly quantitatively removed during the manufacturing process, to date there is no evidence that the consumer ready product is truly free of residues (Monaci $\boldsymbol{e t} \boldsymbol{a l}$., 2017).

Commercially available bottled wines made using standardized processes, fining, maturation, and filtration, do not therefore represent any risk of anaphylactic reactions in sensitized people (Lifrani et al., 2017; Cho et al., 2015; Munblit and Verhasselt, 2016). Rolland et al. (2006) investigated whether wines fined with allergenic proteins (such as milk proteins, isinglass and egg proteins) can provoke significant clinical allergic reactions in sensitive patients. Although the consumption of milk protein-fined wine did not induce anaphylaxis, some mild reactions were observed. In view of this, it is of paramount importance to have at disposal sensitive analytical methods able to detect traces of milk and egg allergens in food (de Angelis et al., 2017).

Several analytical methods exist for the quantitative and qualitative detection of residues of priority allergenic foods. These include methods such as enzymelinked immunosorbent assays (ELISAs), lateral flow assays, and polymerase chain reaction (PCR) methods, which are currently available commercially for detecting residues from allergenic sources. Methods such as mass spectrometry (MS) and surface plasmon resonance (SPR) biosensors have only recently been applied to the detection and quantification of allergenic residues in wine. In this context criteria for the methods of quantification of potentially allergenic residues of fining agent proteins in wine were examined (Žiarovská et al., 2018; Baumert, 2013; Rona et al., 2007; Poms et al., 2004 etc.). Several ELISA procedures have been developed to detect allergenic residues in wines. However, the complexity of the wine matrix can inhibit the immunoenzymatic reaction (Koestel et al., 2016). In paper of Monaci et al. (2017) a method using a capillary LC separation combined with ESI-Q-TOF mass spectrometry for the 
unequivocal identification of peptides from caseins is described. The method has been applied to white wine fined with caseinate where some peptides, arising from $\alpha$ and $\beta$ caseins, present as residues in wine extracts could be detected and identified. The method appears to be very useful for screening purposes as well as a confirmative method to corroborate positive results obtained by ELISA.

The exemption for the wine labeling regarding casein and ovalbumin, according the European Directive 2003/89/EC, has been revoked following the negative Scientific Opinion of European Food Safety Authority. EFSA concludes that wines fined with casein / caseinate / milk products / egg derivates may trigger adverse reactions in susceptible individuals. Thereby, allergen labeling of wines become compulsory from June 2012. In the wine manufacturing process, casein and egg albumin are frequently used as fining agent proteins for the fining of white, red wines and rosé. The European Regulation 1266/2010 (EC) establishes that all wines, placed on the European market or labeled after 30 June 2012, shall comply with the labeling rules. Commission implementing Regulation (EU) No 579/2012 establishes the requirement to indicate any potentially allergenic ingredient on the labelling of any beverages containing more than $1.2 \%$ by volume of alcohol, and especially egg-based or milk-based products used in making wines.

\section{MATERIAL AND METHODS}

The aim of our research was milk allergen (casein) determination in the process of wine production. For this reason the detection of casein was performed in 35 samples of grapes, must, federweisser (SW - stormy wine) and wine which originated from the wine producers from different wine-growing regions of

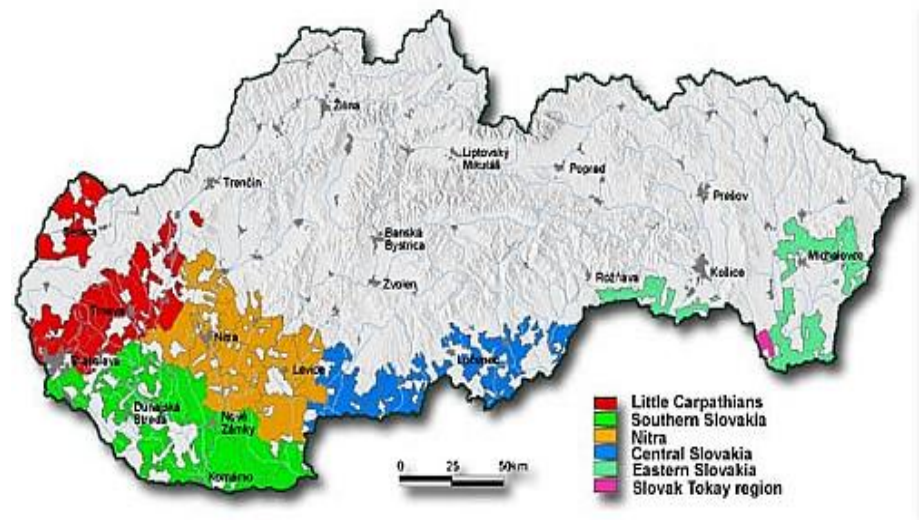

Picture 1 Wine-growing regions of Slovakia

Slovakia. Grape samples of different varieties (9 samples), must ( 3 samples) and federweisser (6 samples) originated from Nitra wine region and Central Slovakian wine region- district Krupina (autumn 2017). Red and white wines (17 samples) used for analysis originated from Nitra wine region and Eastern Slovakian wine region, vintage $2014-2017$

All samples were stored in frozen conditions until the analysis by ELISA kits. Casein ELISA Kit is intended for the quantitative determination of casein in raw as well as heat treated foodstuffs. With use of ELISA Kits were determined all samples in triplicate. Time required for the sample preparation and extraction for 10 samples was about 1 hour. Time required for ELISA determination (96 wells micro-titration plate) was 2 hours $50 \mathrm{~min}$. Limit of detection (LOD): $0.24 \mathrm{ppm}$ $(\mathrm{mg} / \mathrm{kg})$, limit of quantification (LOQ): $1.30 \mathrm{ppm}(\mathrm{mg} / \mathrm{kg})$, calibration scale range: $1.5-45 \mathrm{ppm}(\mathrm{mg} / \mathrm{kg})$.

\section{Principle of analysis}

The determination of casein is based on its immunochemical reaction with a specific antibody. Casein present in analysed sample and casein, having been marked with biotin prior to the analysis, react in the first step with a specific antibody coated on walls of wells, as arrayed in a microtitration plate. As a net result, casein is bound to the wells' walls, while both casein of the sample and that marked with biotin, complete for access to binding spots of the antibody against casein; these spots are limited in their count. Following the step of wells washing, added to the wells is the horse-radish peroxidase conjugated with streptavidin, to undergo an incubation phase. After expiry of the necessary incubation period comes washing out the wells and then the addition of a chromogenic substrate (tetramethylbenzidine) will enable to detect the remaining coated (immobilised) peroxidase. The intensity of colouration thus developed is inversely proportional to the concentration of casein in calibrators, check samples and analysed samples.

\section{Sample preparation}

Grape samples were grinded in grinding mortar to obtain powder material. Liquid samples (must, federweisser and wine) were processed directly. To $1.00 \mathrm{~g}$ or 1.00 $\mathrm{ml}$ of sample contained in a clean closeable flasks was added $10 \mathrm{mlL}$ of extraction buffer solution. The extraction process was running under continuous shaking for $5 \mathrm{~min}$. After completing the extraction, the flask content was centrifuged and the supernatant liquid was sampled. Conditions of centrifuging: R.C.F $=1.800 \times \mathrm{g}$; time $20 \mathrm{~min}$.

\section{Determination procedure}

- $\quad$ STEP 1 (Pipetting) - into every well $150 \mu \mathrm{L}$ of the calibrator or the sample $+50 \mu \mathrm{L}$ biotinilated casein

- $\quad$ STEP 2 (Incubation) - to cover frame with lid, incubate for $90 \mathrm{~min}$. at 18 $25^{\circ} \mathrm{C}$, no shaking,

- $\quad$ STEP 3 (Washing) - suck off and 4 times rinse with the diluted washing solution,

- $\quad$ STEP 4 (Pipetting) - into every well $200 \mu \mathrm{L}$ of the diluted solution of the conjugate,

- $\quad$ STEP 5 (Incubation) - to cover frame with lid, incubate for $60 \mathrm{~min}$. at 18 $25^{\circ} \mathrm{C}$, no shaking,

- $\quad$ STEP 6 (Washing) - suck off and 4 times rinse with the diluted washing solution,

- $\quad$ STEP 7 (Pipetting and incubation) - into every well $200 \mu \mathrm{L}$ of TMP substrate. Incubate for $20 \mathrm{~min}$. at $18-25^{\circ} \mathrm{C}$ in dark,

- $\quad$ STEP 8 (Measurement) - to stop reaction by adding $50 \mu \mathrm{L}$ of the STOP solution, to measure colour change at $450 \mathrm{~nm}$.

\section{RESULTS AND DISCUSSION}

Proteinaceous products are widely used as fining agents during winemaking to remove unwanted insoluble particles and undissolved microscopic particles (colloidal material) from the must or wine to improve stability. Some of them (egg white, caseinates, and fish gelatine) have allergenic potential and the presence of their residues in the final product could represent a risk for allergic individuals (Peñas et al., 2015). Slovakia is home for almost 400 active winemakers producing varietal and quality wines with protected geographical indication and wines with designation of origin from the 19634 hectares of vineyards in 390 municipalities in 6 main wine regions (Picture 1). The Slovak winemakers may be wine-growers themselves, or supply from the growers in neighbouring regions or both.

Prior to the analysis of 35 samples, quality control of ELISA tests was done. C.V. of results $(\mathrm{n}=10)$ for inter and intra assay was $5.6 \%$ and $4.85 \%$. In accordance with the producer's declared quantitation range, it is possible correctly quantify the contamination between $0-45 \mathrm{ppm}(\mathrm{mg} / \mathrm{kg})$ of cow casein presence in the examined samples. The starting point for obtaining of relevant data was to create 2 calibration curves from the values given in the table 1 .

Table 1 The values for the creation of calibration curve for the detection of cow milk casein in samples by ELISA tests.

\begin{tabular}{cccc}
\hline \multirow{2}{*}{ Standards } & $\begin{array}{c}\text { Concentration of cow milk casein in } \\
\text { the standard [mg/kg] }\end{array}$ & $\begin{array}{c}\text { Analysis of grape, must and } \\
\text { federweisser }\end{array}$ & Analysis of wine \\
\hline $\mathbf{1}$ & 0 & 1.197 & 0.683 \\
\hline $\mathbf{2}$ & 1.5 & 0.44 & 0.763 \\
\hline $\mathbf{3}$ & 4.5 & 0.28 & 0.492 \\
\hline $\mathbf{5}$ & 15 & 0.252 & 0.322 \\
\hline Negative control & 45 & & 0.275 \\
\hline Positive control & Control & 1.990 & 1.875 \\
\hline
\end{tabular}


The results show that accuracy of detection is directly affected by the quality of calibration curve that has significant importance for objective evaluation of the quality detection. As it is presented in the figures 1 and 2, logarithmically modified data needed for creation of calibration curves had linear dependence and detection reliability was described by regression equations. The degree of the variability calibration as expressed $\mathrm{R}^{2}$ was not less than 0.9 in both calibration curves ( 0.9485 and 0.9659 , respectively).

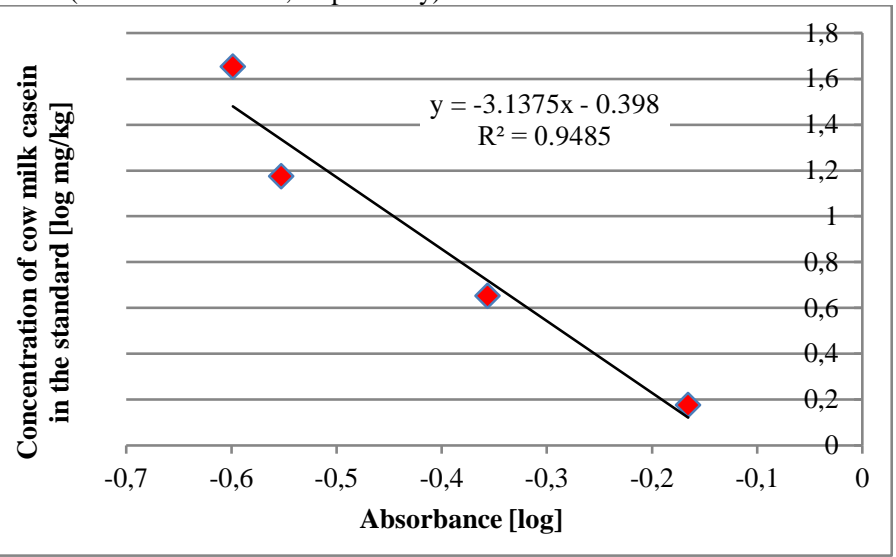

Figure 1 Calibration curve for the detection of cow milk casein in the sample of grape, must and federweisser

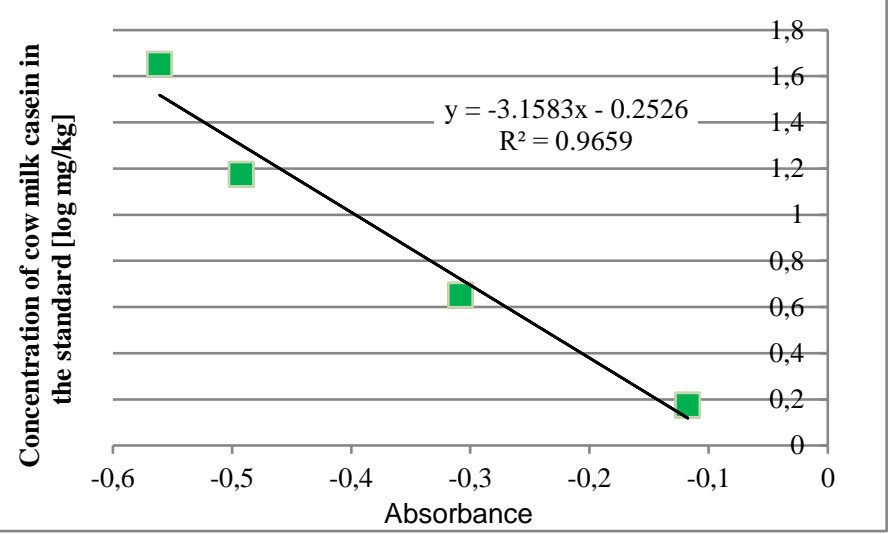

2,5000

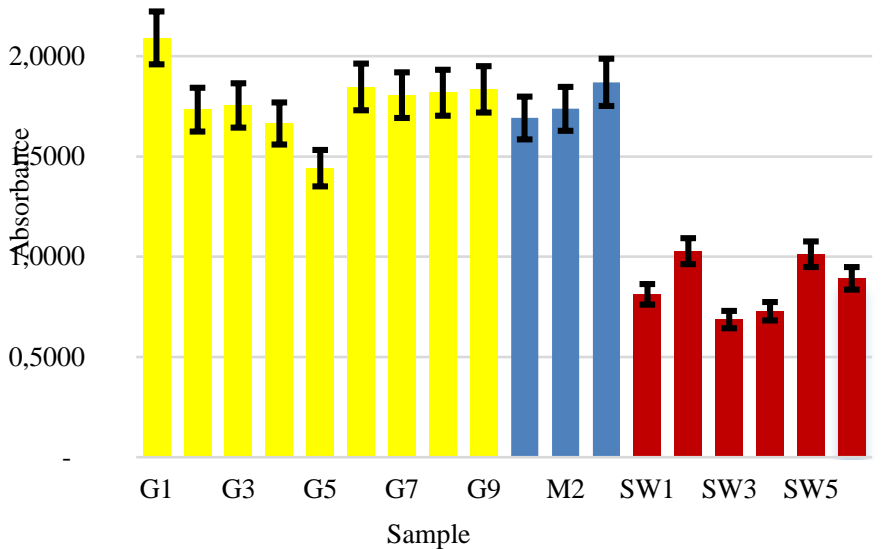

Figure 3 Absorbance of milk casein in the sample of grape, must and federweisser (SW)

Numerous producers and sellers offer their own softwares for imunoanalytical data processing and these are also the part of fotometric analysers (fourparametric logistic model and spatial comparison method). Czerwenka et al. (2010), Zeleňáková et al. (2010, 2011, 2016a), Zarranz and Izco (2007), Asensio et al. (2008) have studied the calibration relationships in frame of chromatographic and ELISA detection of cow milk in the wide spectrum of food In research of Zeleňáková et al. (2016a) the $\mathrm{R}^{2}$ values ranged from 0.9981 up to 0.9956 for the linear regression and $R^{2}$ were 1 in two experiments for the polynomial regression models within interspecies milk adulteration.

Some of the wine samples were succesfully quantified due to their decimal dilution prior to the analysis (table 3 ). The presence of cow milk casein in samples was calculated multiplying by diluting factor. The producer of ELISA kit does not recommend samples to be quantified over/under the detection limit. In grape samples, we detected concentrations of cow's milk casein below the detection limit that is required by the ELISA kit manufacturer. All grape samples had the casein concentration less than the value corresponding to $0 \mathrm{ppm}$ standard $(0.039-0.127 \mathrm{mg} / \mathrm{kg})$. Equally low concentrations were recorded in three samples of must $(0.056-0.077 \mathrm{mg} / \mathrm{L})$. It seems that, under regular consumption of grapes and musts, human health should not be affected in view of the possible allergic reaction to cow's milk protein. In case of federweisser, the casein concentration ranged from $0.367-1.301 \mathrm{mg} / \mathrm{L}$, that is still less than the $1.5 \mathrm{ppm}$ standard (1.373 mg/L).

Table 2 Concentration of cow milk casein in the samples of grafe (G), must (M) and federweisser (SW)

\begin{tabular}{|c|c|c|c|c|c|c|}
\hline Sample & Grape variety & $\begin{array}{c}\text { Wine-growing region } \\
\text { of Slovakia }\end{array}$ & $\begin{array}{l}\text { Average of } \\
\text { absorbance } \\
\quad(n=3)\end{array}$ & Log (abs) & Equation & $\begin{array}{c}\text { Concentration of cow } \\
\text { milk casein }(\mathrm{mg} / \mathrm{kg} \text { and } \\
\mathrm{mg} / \mathrm{L})\end{array}$ \\
\hline G1 & Pálava & Nitra & 2.092 & 0.321 & -1.404 & $0.039(*)$ \\
\hline G2 & Dornfelder & Nitra & 1.734 & 0.239 & -1.148 & $0.071(*)$ \\
\hline G3 & Rizling vlašský & Nitra & 1.755 & 0.244 & -1.164 & $0.068(*)$ \\
\hline G4 & Cabernet Savignon & Nitra & 1.665 & 0.221 & -1.093 & $0.081(*)$ \\
\hline G5 & Müller Thurgau & Nitra & 1.442 & 0.159 & -0.897 & $0.127(*)$ \\
\hline G6 & Frankovka modrá & Nitra & 1.847 & 0.267 & -1.234 & $0.058(*)$ \\
\hline G7 & Othello & Central Slovakia & 1.806 & 0.257 & -1.204 & $0.063(*)$ \\
\hline G8 & Concordia & Central Slovakia & 1.818 & 0.260 & -1.213 & $0.061(*)$ \\
\hline G9 & Iršai & Nitra & 1.835 & 0.264 & -1.225 & $0.060(*)$ \\
\hline M1 & Pálava & Nitra & 1.692 & 0.228 & -1.115 & $0.077(*)$ \\
\hline M2 & Dornfelder & Nitra & 1.738 & 0.240 & -1.151 & $0.071(*)$ \\
\hline M3 & Othello + Concordia & Central Slovakia & 1.870 & 0.272 & -1.251 & $0.056(*)$ \\
\hline SW1 & Othello & Central Slovakia & 0.813 & -0.090 & -0.115 & 0.767 \\
\hline SW2 & Modrá concordia & Central Slovakia & 1.028 & 0.012 & -0.436 & 0.367 \\
\hline SW3 & Müller Thurgau & Nitra & 0.687 & -0.163 & 0.114 & 1.301 \\
\hline SW4 & Andre & Nitra & 0.728 & -0.138 & 0.034 & 1.081 \\
\hline SW5 & Svätovavrinecké & Nitra & 1.013 & 0.005 & -0.415 & 0.384 \\
\hline SW6 & Savignon Blanc & Nitra & 0.892 & -0.049 & -0.243 & 0.572 \\
\hline
\end{tabular}

* the Producer of ELISA kit does not recommend that samples to be quantified under the detection limit 
Increased concentrations of milk casein in federweisser can be found due to the first fermentation or federweisser clarification. At grape processing and pressing, sludge particles are getting to the must containing tannins, polyphenols, chemica residues, wild yeasts and other substances that negatively affect the fermentation process and the overall quality of the wine produced. For this reason, these substances and microorganisms are removed from the federweisser by decanting. This process is often associated with the process of clarification using milk proteins. Milk and egg proteins are commonly used as fining agents for wine production. They remove undesirable substances such as phenolic compounds to prevent coagulation of colloidal particles, reduce bitterness and astringency, resulting in pure wines with no foreign odours (Tolin et al., 2012). In table 3 are shown the cow's milk casein concentrations $[\mathrm{mg} / \mathrm{L}]$ that have been quantified in wine samples.

\begin{tabular}{|c|c|c|c|c|c|c|}
\hline Sample & Grape variety & $\begin{array}{l}\text { Wine-growing } \\
\text { region of } \\
\text { Slovakia }\end{array}$ & $\begin{array}{c}\text { Average of } \\
\text { absorbance } \\
(n=3)\end{array}$ & $\log (\mathbf{a b s})$ & Equation & $\begin{array}{c}\text { Concentration of } \\
\text { cow milk casein } \\
(\mathrm{mg} / \mathrm{L})\end{array}$ \\
\hline W1 & Muškát moravský (2016) & Eastern Slovakia & 0.278 & -0.554 & 1496 & 31.692 \\
\hline W2 & Rulandské šedé (2016) & Eastern Slovakia & 0.315 & -0.502 & 1.332 & 21.473 \\
\hline W3a & Rizling vlašský (2016) & Eastern Slovakia & 0.455 & -0.342 & 0.828 & $\begin{array}{c}67.22 \text { (** undiluted } \\
\text { sample) }\end{array}$ \\
\hline W4 & Dievčie hrozno (2016) & Eastern Slovakia & 0.263 & $-0,580$ & 1.579 & 37.962 \\
\hline W5 & Frankovka modrá (2016) & Eastern Slovakia & 0.618 & -0.209 & 0.408 & 2.556 \\
\hline W6 & Cabernet savignon (2016) & Eastern Slovakia & 0.507 & -0.295 & 0.679 & 4.776 \\
\hline W7 & Rulandské modré (2016) & Eastern Slovakia & 0.712 & -0.148 & 0.213 & 1.634 \\
\hline W8 & Dornfelder (2016) & Eastern Slovakia & 0.389 & -0.410 & 1.042 & 11.027 \\
\hline W9a & Chardonay (2015) & Nitra & 0.504 & -0.298 & 0.687 & $\begin{array}{c}48.66(* * \text { undiluted } \\
\text { sample) }\end{array}$ \\
\hline W10 & Fragolino Bianco (2016) & Nitra & 0.275 & -0.561 & 1.518 & 32.973 \\
\hline W11 & Ríbezl'ové víno (2017) & Nitra & 0.654 & -0.184 & 0.330 & 2.137 \\
\hline W12 & Frankovka Modrá (2014) & Nitra & 0.341 & -0.467 & 1.223 & 16.715 \\
\hline W13 & Frankovka modrá (2015) & Nitra & 0.479 & -0.320 & 0.757 & 5.715 \\
\hline W14 & Frankovka modrá (2016) & Nitra & 0.643 & -0.192 & 0.353 & 2.225 \\
\hline W15 & Svätovavrinecké (2016) & Nitra & 0.327 & -0.485 & 1.281 & 19.081 \\
\hline W16 & Pálava & Nitra & 0.354 & -0.451 & 1.172 & 14.852 \\
\hline W17 & Dornfelder & Nitra & 0.357 & -0.447 & 1.160 & 14.461 \\
\hline
\end{tabular}

** the Producer of ELISA kit does not recommend that samples to be quantified over the detection limit

As it is shown in Table 3, most of wine samples were determined to be in the ELISA detection range. The exceptions were just samples no. 3 and 9, whose absorbance was above the highest standard $(45 \mathrm{mg} / \mathrm{kg})$. These samples were then reconsidered after the first dilution, the resulting cow milk casein concentration was $67.22 \mathrm{mg} / \mathrm{kg}$ and $48.66 \mathrm{mg} / \mathrm{L}$. Higher concentrations of this protein contained white wines (from 21.473 to $67.22 \mathrm{mg} / \mathrm{L}$ ). In red wines, the milk protein concentrations ranged from 1.634 to $16.715 \mathrm{mg} / \mathrm{L}$.

Since July 1st 2012, according to the European Regulation 1266/2010 (EC) all wines placed on the European market shall comply with the labeling rules. The 2003/89/EC directive requests allergen labeling for wine if egg and milk protein were used during the winemaking process and are present at levels $0.25 \mathrm{mg} / \mathrm{L}$ $(0.25 \mathrm{ppm})$ or higher.

Milk proteins (casein, potassium caseinate) are used in the process to remove phenols and tannins from white wine, and egg proteins are used to remove tannin compounds from red wine. The proteins are added to the wine and the precipitates are removed (Rolland et al., 2006). The mechanism of action consists in their interaction with polyphenols to form complexes which can be further removed by decantation or filtration (Castillo-Sánchez, 2006). These proteins are included in the list of allergenic substances and must appear on the label when they are added to the food as ingredients. Conversely, when used as additives for wine production, these products were temporarily excluded from the obligation to label them because of the lack of scientific evidence of their actual presence as residual proteins in wines (Tolin $\boldsymbol{e t .}$ al., 2012). Laboratory analyzes are much more complicated in red than in white wines because it is difficult to obtain and analyze proteins because of the presence of a large number of polyphenols and carbohydrates (Moreno-Arribas et. al., 2002).
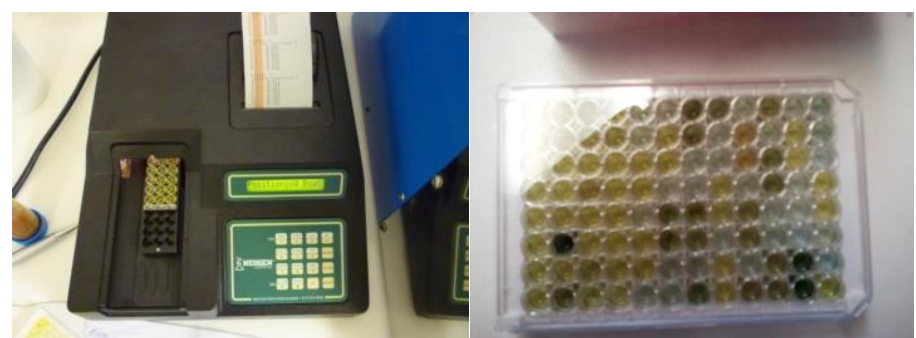

Picture 4 Measurement of absorbance by spectrophotometer at $450 \mathrm{~nm}$ and visualization of ELISA test after addition Stop solution

Milk and egg are renowned allergens often used as fining agents to promote clarification of wines, therefore any residual amount in the end-products could represent a menace for allergic individuals (de Angelis et al., 2017). The aim of the study of Lifrani et al. (2009) was to design sandwich ELISA tests specific to each fining agent in order to detect their residue antigenicity, both during wine processing and in commercially available bottled wines. Sensitized mice and sandwich ELISA methods were established to test a vast panel of wines. The results showed that they were positive to our highly sensitive sandwich-ELISA tests. ELISA is the most widely used form of immunoassay in milk analysis and has advantages of high sensitivity, low cost and fast application. It is easy to use reliable, rapid and readily automated (Zeleňáková et al. 2008, 2011, 2016b; Costa et al., 2008). To implement ELISA assay for the detection of ovalbumin in red wines using commercially available antibodies tested Koestel et al. (2016) The specificity of the acquired antibodies and the absence of cross reactivity were assessed by immunoblotting and ELISA. ELISA assay with LOD of $14.2 \mu \mathrm{g} / \mathrm{L}$ and a LOQ of $56.4 \mu \mathrm{g} / \mathrm{L}$ of ovalbumin in aqueous solution was obtained (Koeste et al., 2016).

The O.I.V. (International Organization of Vine and Wine) through the Oivcomex 502-2012 resolution: revision of the limit of detection and limit of quantification related to potentially allergenic residues of fining agent proteins in wine establishes the following requirements for ELISA test systems: LOD $=0.25$ $\mathrm{ppm}$ and $\mathrm{LOQ}=0.5 \mathrm{ppm}$. ELISA kit used in our analysis had these parameters: Limit of detection (LOD): $0.24 \mathrm{ppm}(\mathrm{mg} / \mathrm{kg}$ ), limit of quantification (LOQ): 1.30 $\mathrm{ppm}(\mathrm{mg} / \mathrm{kg})$, calibration scale range: $1.5-45 \mathrm{ppm}(\mathrm{mg} / \mathrm{kg})$.

The devised UF based method coupled with peptide on-line pre-enrichment enabled to reach the lowest LODs down at $0.036 \mathrm{mg} / \mathrm{mL}$ and $0.05 \mathrm{mg} / \mathrm{mL}$ for egg and milk allergens respectively, proving to be the most sensitive strategy for monitoring allergens contamination in wine (de Angelis et al., 2017). Concerning wine samples, the widespread method used for the detection of caseins is based on antibody recognition. Several enzyme-linked-immunosorbent-assay (ELISA) formats have been recently developed for detection of casein residues in wine samples, with the lowest limit of detection $8 \mathrm{ng} / \mathrm{ml}$. Quantitative ELISA method for determination of caseins in white and rose wines ranged from 0.01 to $10 \mathrm{mg} / \mathrm{L}$, was reported by Weber et $\boldsymbol{a l}$. (2007). Sensitive and specific enzymelinked immunosorbent assays (ELISA) were developed and established for the proteins casein, ovalbumin, and peanut. Lower limit of detection of these proteins was $8 \mathrm{ng} / \mathrm{mL}$. Samples of 153 commercially available bottled Australian wines were tested by these assays and except for two red wines known to contain added whole eggs, residuals of these food allergens were not detected in any wine. These findings are consistent with a lack of residual potentially allergenic egg-, milk-, or nut-derived processing aids in final bottled wines produced in Australia according to good manufacturing practice at a concentration that could cause an adverse reaction in egg, milk, or peanut/tree-nut allergic adult consumers (Rolland et al., 2008)

\section{CONCLUSION}

Method based on immunoenzymatic reaction for the detection and identification of casein in products of grape processing was described. This is important step towards the development of more sensitive method for the detection/identification of markers of potentially allergenic milk proteins used as 
wine fining agents. The findings obtained in the present investigation appear to be important also from the consumer health point of view. Higher concentrations of this protein contained white wines (from 21.473 to $67.22 \mathrm{mg} / \mathrm{L}$ ). In red wines, the milk protein concentrations ranged from 1.634 to $16.715 \mathrm{mg} / \mathrm{L}$. Since caseins may trigger allergic reactions in sensitive consumers, it important to check for their presence also in these products.

Acknowledgments: This research was supported by KEGA 007SPU-4/2017 and VEGA 1/0411/17

\section{REFERENCES}

ASENSIO, L., GONZÁLEZ, I., GARCÍA, T. et al. 2008. Determination of food authenticity by enzyme-linked immunosorbent assay (ELISA). Food Contr., 19 , 1-8. https://doi.org/10.1016/j.foodcont.2007.02.010

BAUMERT, J. L. 2013. Detecting and Measuring Allergens in Food. Risk Management for Food Allergy, 215-226 ISBN 9780123819888 https://doi.org/10.1016/b978-0-12-381988-8.00013-0

BERES, C., COSTA, G. N. S., CABEZUDO, I., DA SILVA-JAMES, N. K. TELES, A. S. C., CRUZ, A. P. G., MELlingER-SILVA, C., TONON, R. V., CABRAL, L. M. C., FREITAS, S. P. 2017. Towards integral utilization of grape pomace from winemaking process: A review. Waste Management, 68, 581-594. https://doi.org/10.1016/j.wasman.2017.07.017

CASTILLO-SÁNCHEZ, J. J., MEJUTO, J. C., GARRIDO, J., GARCÍA FALCON S. 2006. Influence of wine-making protocol and fining agents on the evolution of the anthocyanin content; colour and general quality of Vinhão wines. Food Chem., 97, 130-136. https://doi.org/10.1016/j.foodchem.2005.03.030

CASTILLO-VERGARA, M., ALVAREZ-MARIN, A., CARVAJAL-CORTES, S. 2015. Implementation of a cleaner production agreement and impact analysis in the grape brandy (pisco) industry in Chile. J. of Cleaner Production, 96, 110 117. https://doi.org/10.1016/j.jclepro.2013.09.048

COSTA, N., RAVASCO, F., MIRANDA, R. 2008. Evaluation of a commercial ELISA method for the quantitative detection of goat and cow milk in ewe milk and cheese. Small Ruminant Res., $79 \quad$ (1), 73-79. https://doi.org/10.1016/j.smallrumres.2008.07.012

CZERWENKA, CH., MULLER, L., LINDNER, W. 2010. Detection of the adulteration of water buffalo milk and mozzarella with cow's milk by liquid chromatography-mass spectrometry analysis of $\beta$-lactoglobulin variants. Food Chem., 122, 901-908. https://doi.org/10.1016/j.foodchem.2010.03.034

CHO, C. Y., NOWATZKE, W., OLIVER, K., GARBER, E. A. E. 2015. Multiplex detection of food allergens and gluten. Analytical and Bioanalytical Chemistry, 407 (14), 4195-4206. https://doi.org/10.1007/s00216-015-8645-y

DE ANGELIS, E., PILOLLI, R., MONACI, L. 2017. Coupling SPE on-line preenrichment with HPLC and MS/MS for the sensitive detection of multiple allergens in wine. Food Control, 73, 814-820. https://doi.org/10.1016/j.foodcont.2016.09.031

Directive 2003/89/EC of the European Parliament and of the Council amending Directive 2000/13/EC as regards indication of the ingredients present in foodstuffs.

Commission Regulation (EU) No 1266/2010 of 22 December 2010 amending Directive 2007/68/EC as regards labelling requirements for wines

Commission Implementing Regulation (EU) No 579/2012 of 29 June 2012 amending regulation (EC) No 607/2009

FERREIRA, R. B., PICARRA-PEREIRA, M. A., MONTEIRO, S., LOUREIRO V. B., TEIXEIRA, A. R. 2001. The wine proteins. Trends in Food Science \& Technology, 12 (7), 230-239. https://doi.org/10.1016/s0924-2244(01)00080-2 GAŽAROVÁ, M., CHLEBO P., TURIANICA, I., SLEZÁK, F., ROSTOKA, L. 2008. Analysis of selected wine types focused on their antioxidant capacity and activity. Visnik stomatologii, 64 (4), 45-46.

GAŽAROVÁ, M., HABÁNOVÁ, M., CHLEBO P., KOPČEKOVÁ, J. 2010. Effect of moderate red wine consumption on the development and progression of metabolic syndrome as a complex risk factor for cardiovascular disease and diabetes mellitus. Potravinárstvo ${ }^{\circledR}$ Scientific Journal for Food Industry, 4, 22-27. http://doi: 10.5219/91

GAŽAROVÁ, M., CHLEBOVÁ, Z., PREDNÁ L., CHLEBO P., HABÁNOVÁ, M. 2016. The changes in biochemical parameters due to wine consumption depending on gender. Potravinárstvo ${ }^{\circledR}$ Scientific Journal for Food Industry, 10 (1), 437-443. http://doi:10.5219/634

HE, F., LIANG, N. N., MU, L., PAN, Q. H., WANG, J., REEVES, M. J., DUAN, C. Q. 2012. Anthocyanins and their variation in red wines I. Monomeric anthocyanins and their color expression. Molecules, 17 (2), 1571-1601 https://doi.org/10.3390/molecules17021571

KOESTEL, C., SIMONIN, C., BELCHER, S., RÖSTI, J. 2016. Implementation of an Enzyme Linked Immunosorbent Assay for the Quantification of Allergenic Egg Residues in Red Wines Using Commercially Available Antibodies. J. Food Science, 81 (8), 2099-2106. https://doi.org/10.1111/1750-3841.13378

LIFRANI, A., DOS SANTOS, J., DUBARRY, M., RAUTUREAU, M. BLACHIER, F., TOME, D. 2009. Development of animal models and sandwichELISA tests to detect the allergenicity and antigenicity of fining agent residues in wines . J. Agric. Food Chem., 57 (2), 525-534. https://doi.org/10.1021/jf8024584
MORENO-ARRIBAS, M. V., PUEYO, E., POLO, M. C. 2002. Analytical methods for characterization of proteins and peptides in wines. Analytica Chimica acta, 458 (1), 63-75. https://doi.org/10.1016/s0003-2670(01)01531-8 MONACI, L., LOSITO, I., PALMISANO, F., VISCONTI, A. 2010 Identification of allergenic milk proteins markers in fined white wines by capillary liquid cromatography-electrospray ionization-tandem mass spectrometry. Journal of Cromatography A, 1217 (26), 4300-4305. https://doi.org/10.1016/j.chroma.2010.04.035

MUNBLIT, D., VERHASSELT, V. 2016. Allergy prevention by breastfeeding: possible mechanisms and evidence from human cohorts. Current Opinion in Allergy and Clinical Immunology, $16 \quad$ (5), 427-433. https://doi.org/10.1097/aci.0000000000000303

PEÑAS, E., DI LORENZO, C., UBERTI, F., RESTANI, P. 2015. Allergenic proteins in enology: A review on technological applications and safety aspects Molecules, 20, 13144-13164. https://doi.org/10.3390/molecules200713144

POMS, R.E., KLEIN, C.L., ANKLAM, E. 2004. Methods for allergen analysis in food: A review. Food Additives and Contaminants, 21 (1), 131. https://doi.org/10.1080/02652030310001620423

RAPOSO, R., CHINNICI, F., RUIZ-MORENO, M. J., PUERTAS, B., CUEVAS, F. J., CARBÚ, M., GUERRERO, R. F., ORTIZ-SOMOVILLA, V., MORENO-ROJAS, J. M., CANTOS-VILLAR, E. 2018. Sulfur free red wines through the use of grapevine shoots: Impact on the wine quality. Food Chemistry, 243, 453-460. https://doi.org/10.1016/j.foodchem.2017.09.111

ROLlAND, L. M., APOSTOLOU, E., DECKERT, K., DE LEON, M. P., DOUGLASS, J. A., GLASPOLE, I. N., BAILEY, M., STOCKLEY, C. S . O'HEHIR, R. E. 2006. Potential food allergens in wine: Double-blind, placebocontrolled trial and basophil activation analysis. Nutrition, 22 (9), 882-888 https://doi.org/10.1016/j.nut.2006.06.002

ROLLAND, J. M., E. APOSTOLOU, E., DE LEON, M. P., STOCKLEY, C. S. O' HEHIR, R. E. 2008. Specific and sensitive enzyme-linked immunosorbent assays for analysis of residual allergenic food proteins in commercial bottled wine fined with egg white, milk, and nongrape-derived tannins. J. Agric. Food Chem., 53 (2), 349-354. https://doi.org/10.1021/jf073330c

RONA, R. J., KEIL, T., SUMMERS, C., GISLASON, D., ZUIDMEER, L., SODERGREN, E., SIGURDARDOTTIR, S. T., MADSEN, C. 2007. The prevalence of food allergy: A meta-analysis. J. Allergy and Clinical Immunology, 120 (3), 638-646. https://doi.org/10.1016/j.jaci.2007.05.026 TOLIN, S., PASANI, G., SIMONATO, B., MAINENTE, F., ARRIGONI, G. 2012. Analysis of commercial wines by LC-MS/MS reveals the presence of residual milk and egg white allergens. Food Control, 28 (2), 321-326. https://doi.org/ S0956713512002381

WEBER, P., STEINHART, H., PASCHKE, A. 2007. Investigation of the allergenic potential of wines fined with various proteinogenic fining agents by ELISA. J. Agric. Food Chem., 55, 3127-3133. https://doi.org/10.1021/jf063436s ZARRANZ, M. J., IZCO, J. M. 2007. Validation parameters of an ELISA to detect presence of milk from other species. Milchwiss.: Journal of Nutrition Research and Food Science. Kempten : AVA Agrar-Verlag Allgäu. 62 (2), 159 163.

ZELEŇÁKOVÁ, L., GOLIAN, J., ZAJÁC, P. 2008. Application of ELISA tests for the detection of goat milk in shep milk. Milchwiss : Journal of Nutrition Research and Food Science. Kempten : AVA Agrar-Verlag Allgäu. 63 (2), 137 141.

ZELEŇÁKOVÁ, L., ŽIDEK, R., ČANIGOVÁ, M., PAULOV, J., GALLISOVÁ, T. 2010. Evaluation of ELISA method to detection of cow $\beta$-lactoglobulin in sheep milk and sheep milk products. Potravinárstvo ${ }^{\circledR}$ Scientific Journal for Food Industry, 4 (4), 80-84. https://doi.org/10.5219/78

ZELENÁKOVÁ, L., ŽIDEK, R., ČANIGOVÁ, M. 2011. Optimalization of ELISA method for detection of bovine $\beta$-lactoglobulin in sheep milk and sheep milk products. Milchwiss.: Journal of Nutrition Research and Food Science. Kempten : AVA Agrar-Verlag Allgäu. 66 (3), 278-281.

ZELEŇÁKOVÁ, L., BOBKOVÁ, A., FIKSELOVÁ, M. 2016a. ELISA tests reliability within raw and heat - treated cow milk detection in sheep milk and cheese. In Foodintegrity 2016. Praha : Vysoká škola chemicko-technologická, 175.

http://www.foodintegrity2016.eu/pdf/BoA FI2016 final.pdf>.

ZELEŇÁKOVÁ, L., ŽIDEK, R., ČANIGOVÁ, M., ŽIAROVSKÁ, J., ZAJÁC P., MARŠÁLKOVÁ, L., FIKSELOVÁ, M., GOLIAN, J. 2016b. Research and practice: quantification of raw and heat-treated cow milk in sheep milk, cheese and bryndza by ELISA method. Potravinárstvo ${ }^{\circledR}$ Scientific Journal for Food Industry, 10 (1), 14-22. http://dx.doi.org/10.5219/566>

ŽIAROVSKÁ, J.,ZELEŇÁKOVÁ, L., CUSIMAMANI F. E., KAČÁNIOVÁ, M. 2018. A thaumatin-like genomic sequence identification in Vitis vinifera L., stormy wines and musts based on direct PCR. Potravinárstvo ${ }^{\circledR}$-Scientific Journal for Food Industry, 12 (1), 226-232. https://doi.org/10.5219/892 